The Labore Journal of Economics

Special Edition

\title{
Pakistan's Poverty Reduction Strategy: Why Employment Matters ${ }^{1}$
}

\section{Rashid Amjad}

\section{Introduction}

Despite some slight improvement in the last two years the overall employment and labor market situation continues to give rise to serious concern and needs to be given the highest attention in economic and social policy making in Pakistan. The rise in unemployment rate from around 3 per cent in the early 1990 s to around 8 per cent in recent years in a country where few people can afford not to work for a lack of any effective safety net, reflects the emergence of a serious imbalance in the labor market. This more than doubling of the unemployed from around 1 million in 1990 to around 3.5 million in 2003-04 has been, as we shall argue, a major contributory factor in the rise in poverty during the 1990s. The severity of the employment problem is reflected in the fact that unemployment in recent years has been higher amongst the poor than the non-poor in the labor force.

The high rates of open unemployment are only partly reflective of the weak demand for labor in relation to its supply. Pakistan's major employment challenge is that a large proportion of the labor force earn extremely low incomes and work in hazardous and poor working conditions. The ILO estimates that there were around 15 million "working poor" or one-third of the labor force that lived on less than $\$ 1$ a day in $2001-02$.

In addition the labor market suffers from serious gender disparity. Female unemployment rates are double that of men at around 13 per cent in 2003-04 (down from 16.5 per cent in 2001-02). Unemployment among young people in the 15-24 age group was around 24 per cent in 2003-04 i.e. more than three times the overall unemployment rate. $^{2}$

\footnotetext{
${ }^{1}$ The author is Director (Policy Planning), Employment Sector, ILO Geneva. The views expressed in the article are his own and do not necessarily represent those of the ILO.

2 All data comparing 2003-04 with 2001-02 are based on Federal Bureau of Statistics, Labor Force Survey 2003-04, Islamabad.
} 
This grim employment situation is compounded by the low level and quality of skills of Pakistan's work force. More than half of Pakistan's labor force is illiterate and most skills have been acquired through on-the-job training in the informal economy. This seriously constrains the country's ability to compete in a global economy where the pace of competition is intensifying as the new WTO regime unfolds.

Pakistan like most other developing countries has found it extremely difficult to create good quality jobs in the formal or organised sector. Over the last ten years most of the new jobs have been created in the informal economy and this trend has accelerated as seen by the increase of the share of the informal economy in non-agriculture employment from 64.6 per cent in 2001-02 to 70 per cent in 2003-04. There has also been a corresponding increase in contract and other precarious forms of employment. This increase in informal sector employment and hiring of contract workers in the organised sector is reflective of the general slackening of the labor market and a decline in the bargaining position of labor. It could also partly be the result of a regulatory framework which places a high cost and imposes a lack of flexibility in hiring and dismissing workers for those employing people in the formal or organised sector. ${ }^{3}$

A well functioning labor market is an essential ingredient for developing a sound investment-climate and can play a critical role in stimulating growth and poverty reduction. To the extent that rigidities exist, whether induced by lack or low levels of skills or a constraining regulatory framework, it can adversely impact on job creation especially by small and medium enterprises which are the main engine of employment generation in Pakistan.

That said, it is also important to recognize that labor markets are different from other markets. Labor is not a commodity and labor markets are socially embedded. They rely on human motivations and needs including the need for security and social fairness. Freely chosen productive and remunerative employment must be promoted simultaneously with fundamental rights at work, an adequate income from work and an affordable degree of social protection.

The objective must be to develop an efficient and rights-based labor market based on social dialogue and strong supporting labor market

\footnotetext{
${ }^{3}$ See Asya Akhlaque and Milan Vodopivec, Generating Investment and Employment opportunities in Pakistan through Labor Market Reforms : Concept Note for the Proposed Labor Market Study, Islamabad, 2005
} 
institutions including employers' and workers' organisations. In this context the labor legislation of October 2002, the Industrial Relations Ordinance (IRO) 2002, and changes in the administrative arrangements for the enforcement of labor inspection have given rise to serious concern and some provisions of the IRO (2002) and other legislation are not in conformity with international labor standards which Pakistan has ratified. ${ }^{4}$

The major attention of the government in the four of the last five and a half years i.e. between 1999 to end-2003, was concentrated in restoring macro stability through a stringent fiscal policy stance and a restrictive monetary policy under an IMF program. Having achieved a turnaround on the macro front and the rekindling of economic growth the government is now focussing its attention on job creation and poverty reduction. These priorities are reflected in Pakistan's recently finalized Poverty Reduction Strategy $^{5}$ and its draft Medium Term Development Framework 2005-2010.

Both the Poverty Reduction Strategy and the Draft Medium Term Development Framework recognize that the most effective means of reducing poverty is through the creation of productive and remunerative employment. This paper is divided into two main parts. The first part analysis in a historical context the growth-employment -poverty nexus to show how employment and labor market developments have played a vital if not a decisive role in influencing poverty levels in Pakistan. The second part of the paper reviews the current efforts being undertaken to reduce unemployment and improve the deteriorating labor market situation so as to favourably impact on the high levels of poverty and identifies areas where policies and resources-could be more sharply focussed and areas where new initiatives could be launched.

These relate to the following key areas:

- Generating and sustaining a high rate of economic growrh to create the necessary precondition for more and better jobs for women and men in Pakistan.

\footnotetext{
${ }^{4}$ Specifically Convention No. 87 (Freedom of Association and Protection of the Right to Organise), Convention No. 98 (Right to Organise and Collective Bargaining) and Convention No. 81 (Labor Inspection Convention).

${ }^{5}$ Government of Pakistan, Poverty Reduction Strategy Paper, Accelerating Economic Growth and Reducing Poverty: The Road Ahead, Poverty Reduction Strategy Secretariat, Ministry of Finance, Islamabad, December 2003.

${ }^{6}$ Government of Pakistan, Working Draft, Medium Term Development Framework 2005-10, Planning Commission, Islamabad, March 2005.
} 
- Increasing productivity and incomes in the rural economy while maintaining its labor absorptive capacity.

- Promoting local development, empowering local communities and upscaling successes.

- Creating a favorable environment for entrepreneurship and enterprise development especially for small and medium enterprises.

- Increasing the employment intensity of the public sector investment program by balancing the more capital intensive long gestation mega projects with more labor based targeted interventions.

- Developing a globally competitive work force.

- Striking the best possible balance between flexibility in the labor market for enabling enterprises to adjust while providing security for workers.

- Improving productivity, conditions of work and incomes in the informal economy.

- Maximising development benefits from overseas migration and remittances.

- Mainstreaming gender equality.

- Providing income security and affordable social protection.

- Improving the existing system of labor market monitoring.

\section{Employment and Poverty Challenge}

In examining the employment and poverty challenge facing Pakistan the following important characteristics of the labor market need to be noted.

- With a labor force growth of around 3 per cent, based on historical trends and a healthy growth in productivity, Pakistan's economy must grow at a minimum of 6 per cent to absorb the new entrants into the labor force. It needs to grow even faster if it is to bring down the exceptionally high unemployment rate.

- The slackening in the labor market, as a result of the slowing down in economic growth, is reflected in movement of real wages where except in the public sector, between 1996 and 2002 they declined for both salaried and casual workers. 
- The agricultural sector and allied industry (livestock, poultry and dairy) still account for the bulk of the employed labor force with a slight increase in recent years to around 43 per cent in 2003-04. To reduce pressure on rural to urban migration and corresponding increases in low productivity informal sector employment in urban areas the agricultural economy still needs to play an important part in increasing productivity and incomes while maintaining its labor absorptive capacity.

- Women's participation rate remains extremely low at 16 per cent in contrast to men's participation rate of around 70 per cent. If economic activities carried out within house premises is included this rate increases to 39.3 per cent but still is much less than their male counterparts. ${ }^{7}$

- Outside the agriculture sector, the informal economy employs around 70 per cent of the labor force. The vast majority of informal jobs suffer from low productivity, low incomes and poor and hazardous working conditions.

- While the employment rate among the illiterate is particularly high, as this group can hardly afford not to work, they are disproportionately more likely to be poor.

- Among educated workers, more education not only brings significant wage advantage but is also associated with a higher participation rate particularly among women.

- A significant number of Pakistanis work overseas, variously estimated at between 2 to 3 million, mainly in the Middle-East but also in the Far East and with families in the United States, UK and Europe. Out and return migration to Pakistan and remittances from abroad, which have increased almost four-fold post $9 / 11$ to around $\$ 4$ billion, have played an important role in labor market developments in Pakistan.

- Child labor is estimated at 3.3 million and a significant number in bonded labor.

About one out of thirty-three i.e. 2.8 per cent of the labor force reported some sort of occupational injury or disease in 2003-04. The majority of sufferers fall in the category of the self-employed.

\footnotetext{
${ }^{7}$ For obtaining a better measure of labor participation, especially of females, few new questions to net in a set of economic activities likely to be carried within house premises have been introduced in Labor Force Surveys.
} 


\section{Growth-Employment-Poverty Nexus in Pakistan}

In Pakistan the relationship between growth and poverty has never been straightforward as different time periods of its economic development testify. Periods of high economic growth have witnessed both declines in poverty, as in the 1980s, but also an increase in poverty as in the 1960s. Periods of low economic growth have seen poverty sharply increase as in the 1990 s but also seen poverty fall as in the 1970s. In recent years the revival of economic growth on somewhat limited evidence suggests that poverty levels may again be declining.

While there is now a rich body of literature which reviews these trends and examines the reasons for the fluctuating levels of poverty ${ }^{8}$ as we shall see a key factor in explaining poverty trends has been developments in the labor market, both domestic and external, as these have impacted on employment, wages and the relative bargaining strength of workers.

Table-1: Growth and Poverty

\begin{tabular}{|c|c|c|c|c|c|c|}
\hline Year & $\begin{array}{c}1963-64 \\
\text { to } \\
969-70 \\
\end{array}$ & $\begin{array}{c}1971-72 \\
\text { to } \\
1976-77 \\
\end{array}$ & $\begin{array}{c}1976-77 \\
\text { to } \\
1987-88 \\
\end{array}$ & $\begin{array}{c}1987-88 \\
\text { to } \\
1992-93 \\
\end{array}$ & $\begin{array}{c}1992-93 \\
\text { to } \\
1998-99\end{array}$ & $\begin{array}{c}1998-99 \\
\text { to } \\
2001-02 \\
\end{array}$ \\
\hline GDP Growth rate & 7.2 & 4.8 & 6.7 & 4.8 & 4.2 & 3.2 \\
\hline $\begin{array}{l}\text { Labor Force } \\
\text { Growth rate }\end{array}$ & 1.7 & 3.5 & 2.5 & 1.9 & 3.6 & 2.5 \\
\hline $\begin{array}{l}\text { Growth rate of } \\
\text { employment }\end{array}$ & 1.5 & 3.4 & 2.5 & 1.5 & 3.4 & 1.6 \\
\hline $\begin{array}{l}\text { Changes in } \\
\text { Unemployment rate }\end{array}$ & $\begin{array}{c}0.98 \text { to } \\
1.99\end{array}$ & $\begin{array}{l}2.1 \text { to } \\
2.6\end{array}$ & $\begin{array}{c}2.62 \text { to } \\
3.14\end{array}$ & $\begin{array}{c}3.14 \text { to } \\
4.71\end{array}$ & $\begin{array}{l}4.71 \text { to } \\
5.9\end{array}$ & $\begin{array}{l}5.9 \text { to } \\
8.3\end{array}$ \\
\hline $\begin{array}{l}\text { Changes in Poverty } \\
\text { levels* }\end{array}$ & $\begin{array}{l}40.2 \text { to } \\
46.5\end{array}$ & $\begin{array}{c}46.5 \text { to } \\
30.7\end{array}$ & $\begin{array}{l}30.7 \text { to } \\
17.3\end{array}$ & $\begin{array}{c}17.3 \text { to } \\
22.4\end{array}$ & $\begin{array}{l}25.7 \text { to } \\
32.6\end{array}$ & $\begin{array}{l}30.6 \text { to } \\
32.1\end{array}$ \\
\hline
\end{tabular}

* Data on poverty levels is based on Amjad and Kemal (1997) till 1992-3 and Planning Commission estimates in subsequent years.

Source: A.R. Kemal, Employment-Poverty Linkages and Policy in Pakistan, ILO Working Paper, Geneva, 2005.

\footnotetext{
${ }^{8}$ See for example Rashid Amjad, Solving Pakistan's Poverty Puzzle: Whom Should We Believe? What should We Do?, Pakistan Development Review, Volume 42, Number 4, Winter 2003, Islamabad.
} 
While data may not be strictly comparable in different time periods Table-1 provides fairly robust evidence of the relationship between growth, poverty and labor market developments in Pakistan.

The period from 1987-88 to 2001-02 shows that a slowing down in economic growth accompanied by an increasing imbalance in the supply and demand for labor resulted in a sharp increase in unemployment and a significant rise in poverty levels during this period.

The slowing down in economic growth was the result of large fluctuations and decline in cotton production, continuing slowing down of remittance flows, bad weather conditions which directly affected agricultural production and economic sanctions after Pakistan's nuclear explosion in May 1998. Frequent changes in governments in this period added to economic uncertainty and lack of continuity in economic decision making. Political considerations may also have dictated unsound economic decisions such as the Lahore-Pindi motorway.

In addition to these factors poor economic management worsened the situation. These decisions related to: (i) poor sequencing and pace of the implementation of the economic reform program; (ii) failure to effectively protect real incomes of the poor and vulnerable groups against the rise in prices of essential goods including as a result of removal of food subsidies and increases in energy prices; (iii) targeted lowering or the capping of the fiscal deficit as part of the IMF stand by loan agreements which led to a decline in the public sector development program from around 6.4 per cent of GDP in 1992-93 to only 2.8 per cent in 2000-01; (iv) weakening of the bargaining position of workers in the face of rising unemployment ; and (v) inadequate safety nets for the poor and the vulnerable to deal with the deteriorating economic, employment and poverty situation.

The dynamics of the increase in rural poverty and its relationship with the labor market situation during the 1990s has been demonstrated very effectively in a recent study. ${ }^{9}$ The study examines the issue that while growth was uneven in agriculture during the 1990s, the overall official economic growth for agriculture was still impressive at over 4 per cent per annum, then why did rural poverty sharply increase during this period? While demonstrating through different official sources that actual real growth was in fact lower at around 3.1 per cent he relates the increase in poverty due to the skewed structure of landholdings with more than half of

\footnotetext{
${ }^{9}$ Sohail J. Malik, Agriculture Growth and Rural Poverty, Working Paper No. 2, Pakistan Resident Mission Working Paper Series, Asian Development Bank, Islamabad, 2005.
} 
the total farms being less than 5 acres in size and a slackening in labor demand which adversely affected incomes of the poor rural landless households which comprise more than half of the rural labor force. The smaller farmers are less diversified and vulnerable to poverty as a result of highly erratic yields especially in cotton during this period. The factors responsible for the decrease in the demand for labor were related to mechanization in agriculture which reduced the use of non-farm hired labor, a slowing down in non-farm activities especially construction which was partly due to the decline in the public sector infrastructure development program. This resulted in a decrease in real wages of both agricultural and construction workers which contributed significantly to a rise in poverty in this period.

In sharp contrast in the period from 1976-77 to 1987-88 a high rate of economic growth together with employment and labor force growing around the same level resulted in a decline in poverty even though unemployment increased very slightly. These favorable domestic developments were accompanied by a rapid increase in overseas migration mainly to the Middle- East, with almost one-third of the increase in the labor force in the first five years of this period finding jobs overseas. Remittances also increased rapidly reaching a peak of around $\$ 2.7$ billion, through formal channels, and since these reflected earnings of mainly skilled and semi-skilled workers sent to their families in Pakistan, it stimulated demand for products and jobs in small and medium enterprises and in the housing sector. Real wages increased in all sectors of the economy in response to a tightening of the labor market and poverty declined significantly during this period.

The period 1963-64 to 1969-70 showed that despite an impressive growth rate, low employment growth and a decline in real wages till at least 1967-68 contributed to a rise in poverty. In the period 1971-72 to 1976-77, low economic growth but a fast rate of employment generation including in the public sector, increase in real wages as new labor legislation increased the bargaining position for workers and more secure tenancy rights, together with the start of overseas migration to the Middle-East and remittances led to a decline in poverty mainly during the latter part of this period.

It may be useful to track labor market developments more closely post-2002 which has seen a revival in economic growth and based on projections for 2004-05 the economy would have grown on average at around 6 per cent in the last three years. This has been the result of a much better performance of the agricultural economy and very high growth 
in large scale manufacturing. The latter has been as high as 17.5 per cent in 2003-04. The direct employment generation resulting from this high growth in manufacturing may be somewhat marginal. Textiles are now far less labor intensive and consumer durables (motor vehicles, scooters, air conditioners) are relatively capital-intensive. The massive increase in remittances post $9 / 11$ to around \$ 4 billion or about 7 per cent of GDP in 2002-2002, a level which they have subsequently maintained, may not have had the same impact on employment as in the late 1970s and early 1980s as they appear to be coming mainly from professionals for investment in Pakistan in real estate and stocks, but have contributed significantly to a construction boom mainly in the housing market. Growth of formal sector employment in the last few years has taken place in telecommunications, media and the IT sector. There has also been a significant increase in employment in services related to restaurants and other food facilities in major urban centers.

These favorable developments in the labor market have led to slight reduction in unemployment from 8.3 in 2001-02 to 7.7 per cent in 2003-04 and an increase in real wages of around 10 per cent in this period based on Labor Force Survey data. Wages of unskilled construction workers, masons and carpenters also increased by 11.1, 6.7 and 4.8 per cent respectively in 2003-04 compared to the previous year. Wages in the agriculture sector according to data collected by the Agricultural Prices Commission have not shown any real increase in the same period. ${ }^{10}$

A small sample survey of around 5000 households conducted by the Federal Bureau of Statistics in 2004 suggests a slight decline in poverty compared to 2001 but lack of comparability have raised doubts on its results. That said, when seen in relation to other labor market indicators and the strong revival of economic growth, bumper cotton and an expected good wheat crop in 2004-05, could all point to a reversal in the trend of rising poverty in the country.

To conclude, the overall analysis of the growth-employment-poverty nexus in Pakistan, clearly suggests that whereas growth is a necessary condition for poverty reduction, it is not sufficient. Only if the pattern of growth embraces those sectors where the poor work and is accompanied by an increase in employment whether domestic or overseas, reflected partly in increases in real wages as the labor market improves, will growth have a favorable impact on reducing poverty.

\footnotetext{
${ }^{10}$ See Kemal (2005)
} 


\section{Pakistan's Poverty Reduction Strategy and Medium Term Development Framework}

\section{Poverty Reduction Strategy Paper}

Pakistan's Poverty Reduction Strategy Paper (PRSP) finalized in December 2003 and its recently released Draft Medium Term Development Framework (MTDF) 2005-2010 in March 2005 for debate and discussion both reflect the high priority the government attaches to employment generation as a major element of its poverty reduction strategy and for redressing the serious unemployment situation and low level of skills and productivity of its work force.

The PRSP explicitly recognises employment as an essential component of the poverty reduction strategy by embedding it in its macro economic framework and investment program for accelerating economic growth as well as in a separate section outlining measures for employment creation. It has made a conscious attempt to redress gaps in the Interim-PRSP which had not sufficiently highlighted the importance of employment in poverty generation.

The main elements of the employment strategy outlined in the PRSP are:-

- Growth must emanate from sectors that have greater potential to generate employment.

- Targeted policy interventions for quick relief through short-term employment opportunities.

- Agriculture, housing and construction, small and medium enterprises, information technology and telecommunication identified as key sectors with strong potential to generate jobs.

- Importance of developing supporting infrastructure (aviation, ports, railways and roads) as a huge catalyst for economic activity, employment and economic growth.

- Conduct a review of labor regulations and laws that constrain competition and/or impose high and unnecessary compliance costs.

- Creating a business environment that is supportive of small and medium enterprises.

- A rural development strategy to increase productivity and incomes through (i) overcoming water shortages facing agriculture through 
investment in water infrastructure and improved efficient water management; (ii) encourage corporate agricultural farming by leasing out uncultivated state lands; (iii) develop and support livestock farming that provides 25-30 per cent of income of small farmers and landless livestock producers; (iv) targeted programs for boatless fishermen working as laborers and small boat owners; and (v) accelerated distribution of state owned land to small farmers.

- Technical/Vocational education in all districts of Pakistan through area specific skill programs and developing a demand driven public sector Technical Education and Vocational Training (TEVT) system through active involvement of the private sector.

- Targeting through easier provision of micro credit on soft terms, provision of equal opportunities for women in remunerated employment by accommodating women-oriented work patterns and improved facilities for the education, training and skills development of women.

- Encouraging growth of women entrepreneurs through the establishment of an SME bank and customized financing schemes.

- Elimination of child and bonded labor.

Medium Term Development Framework 2005-10 (Working Draft)

Table-2: Employment Projections

\begin{tabular}{lcccccc}
\multicolumn{1}{c}{ Year } & Population & $\begin{array}{c}\text { Labor } \\
\text { Force }\end{array}$ & $\begin{array}{c}\text { Employe } \\
\text { d Labor } \\
\text { Force }\end{array}$ & $\begin{array}{c}\text { Employment } \\
\text { Growth rate } \\
\text { (\%) }\end{array}$ & $\begin{array}{c}\text { Unemployed } \\
\text { Labor } \\
\text { Force }\end{array}$ & $\begin{array}{c}\text { Unemployment } \\
\text { Rate (\%) }\end{array}$ \\
\hline $\begin{array}{l}2004-05 \\
\text { (Benchmark }\end{array}$ & 151.55 & 46,09 & 42.85 & 2.63 & 3.24 & 7.0 \\
) & & & & & & \\
$2005-06$ & 154.37 & 46.94 & 44.05 & 2.80 & 2,89 & 6.2 \\
$2006-07$ & 157.18 & 47.80 & 45.30 & 2.84 & 2.50 & 5.2 \\
$2007-08$ & 159.97 & 48.65 & 46.63 & 2.94 & 2.02 & 4.1 \\
$2008-09$ & 162.76 & 49.49 & 47,51 & 1.90 & 1.98 & 4.0 \\
$2009-10$ & 165.52 & 50.34 & 48.33 & 1.71 & 2.01 & 4.0 \\
\hline
\end{tabular}

Source: Planning Commission (2005) 
The MDTF aims to reduce the rate of unemployment from around 7 per cent in 2004-05 to 4 per cent by the end of the Plan period 2009-10. It is based on a projected average growth rate of 7.4 per cent over the five year period and an implied employment elasticity of around 0.4 . This would lead to employment growth of around 3 per cent which, being higher than the projected growth of labor, would result in a significant fall in the unemployment rate.

According to the MTDF, "The employment strategy for the Plan period is a unique combination of flexible employment relationship (indicated by a high level of labor and job turnover) and economic and social security of employees (illustrated by an unemployment benefit system) along with labor market policy of activation (which upgrades the skills of the unemployed and thus supports the ongoing transformation of the economy). Furthermore, this strategy promotes equity in income distribution through setting of high enough wages to bring a household out of the poverty trap. It aims at the elimination of the "working poor" along with generation of employment opportunities." 11

The employment flexibility policies principally aim at increasing the demand for labor through public works programs (Tameer-e-Pakistan and Khushal Pakistan Program), encouraging overseas employment and growth of employment generating sectors namely agriculture, small scale manufacturing, information technology and construction.

The employment activation policies encompass technical and vocational training to the unemployed, increasing employability of the educated to meet demands of the private and social sectors, micro-financing facility for the self-employed, setting up of an SME bank, micro-credit facilities through Khushali Bank, micro-credit scheme of Zarai Taraqiati Bank for self-employment, the Pakistan Poverty Alleviation Fund to promote micro finance with around $\$ 350$ million available in resources over the Plan period and the establishment of a labor market information system.

The employment safety net policies include the setting up of a minimum wage to ensure elimination of the working poor, the Provincial Employees Social Security Schemes, Employees Old Age Benefit Institution (EOBI), Public Sector Benevolence Funds and Group Insurance, Workers Welfare Fund, Worker's Children Education Ordinance, Zakat Fund and Bait-u1-Maal fund (Individual Financial Assistance Scheme, Food Subsidy Scheme or Atta Subsidy Scheme).

${ }^{11}$ MTDF (2005) pp. 454-455. 
An important strategic thrust of the MTDF is the development of a 'knowledge economy' to compete in the global economy and therefore emphasis is placed on investing in education and skills development, science and technology and research and development.

\section{Some key questions related to the Poverty Reduction and MTDF Employment Strategy}

There are many common elements especially those related to leading sectors for employment generation between the PRSP and the MTDF employment strategy. Yet there is no doubt that the MTDF presents a more rigorous framework related to increasing the demand for labor, active labor market policies for minimizing labor market mismatch and security for workers through a social protection system and a targeted safety net for those in need. The Draft Framework also put forward the proposal for a minimum wage to reduce poverty and income disparities which is not part of the PRSP.

On the employment projections in the MTDF if the country can achieve a growth rate of 8 per cent and a rapidly rising investment rate to 26 percent of GDP by 2009/10 then many of the elements underlying the employment strategy could be realized resulting in a rate of growth of employment of over 3 per cent and a significant fall in the unemployment rate even if it is not halved.

There are, however, still some important issues and concerns in the MTDF employment strategy that need to be addressed. These relate to:

- There is little discussion on the direct employment generating impact of the proposed Public Sector Development Program especially as regards infrastructure development which would account for around 55 per cent of the Plan outlay.

- The resources allocated for active labor market policies for reskilling of the unemployed or appropriate skilling of those first time labor entrants appears to be very meagre at around Rs. 5 billion in relation to the size of the labor force.

- Similarly schemes for micro-credit and direct poverty eradication programs need to be analyzed in terms of number of people it would cover. Again in terms of resources allocated these appear to be fairly small in relation to the problem being addressed. 
- The use of the minimum wage to lift the working poor who are mainly employed in the informal economy and in rural farm and non-farm activities is a bold initiative but needs to be worked out in terms of mechanisms for fixing the level of the minimum wage and more importantly its enforcement and its impact on employment.

- The various schemes currently in operation provide social protection to a very small segment of the labor force (around 2.25 per cent) ${ }^{12}$ and that too those mainly employed in the formal or public sector. Extending this including unemployment benefits to cover all segments of the labor force i.e. the informal economy and agricultural workers would entail extremely high costs, the financing of which is not covered in the MTDF. Also there needs to be an analysis of the safety net provided by Zakat and Bait ul Maal to see the extent of its coverage and concrete suggestions on how this could be enlarged. Sayeed (2004) based on a World Bank study suggests that if all Zakat proceeds go to the poorest quintile of the population, its income will be augmented by a mere 2 per cent.

\section{Key areas for policy analysis and Proposed New Initiatives}

\subsection{Generating and sustaining a high rate of economic growth}

Achieving a high rate of economic growth is an essential procondition for reducing unemployment and poverty in Pakistan, although as our analysis shows it may not in itself prove to be a sufficient one. The MTDF therefore rightly targets a rate of growth of around 8 per cent which is only slightly higher than what would be needed to absorb the growth in the labor force growing at slightly less than 3 per cent.

The 1abor force estimates in the MTDF have been derived on the assumption that the crude activity rate of 30.4 per cent observed in 2003-04 would continue through the 2005-10 period. These could rise as a result of slowing down of population growth and higher levels of economic activity as they have been doing in the recent past. Also an increasingly educated female labor force could push up their labor force participation rates. At the same time higher levels of enrolment at primary, middle, matric and tertiary education levels could reduce the crude activity rate. On balance the

\footnotetext{
${ }^{12}$ See Asad Sayeed, Social Protection in Pakistan; The Concept, Situation Analysis, and the Way Forward, in proceedings of a joint seminar organized by the Planning Commission, ILO and UNDP on Employment-based Poverty Reduction Strategy for Decent Work in Pakistan, Pakistan Institute of Development Economics, Islamabad, December 2004.
} 
assumed crude activity rate is possibly underestimated in the MTDF. This is all the more reason for aiming for a high growth rate averaging 7.4 per cent of GDP over the five year period.

A key question is whether the economy would be able to generate this targeted rate of growth which though high is not improbable, given Pakistan's capacity to grow at an average of around 6 per cent during the period 196090, (which came to be known as the "Pakistani rate of growth"), before the slow down in the 1990s. This would critically depend on attracting private investment, both foreign and domestic, and an almost three fold increase in public sector investment by the end of the Plan period. The macro framework outlined in the end of the MTDF is not altogether convincing on how the proposed public investment would be financed. The needed fiscal policies to raise these resources need to be spelt out.

Another important issue is whether there is enough flexibility built into the Public Sector Development Program (PDSP) in the MTDF to shift resources towards more employment generating projects in the medium term. Again while this requires more close scrutiny of the MTDF it would appear that the PSDP room for flexibility is seriously constrained by the throw forward of a number of mega infrastructure projects launched in the last three years. It may therefore constrain the PSDP's ability to shift resources towards more labor intensive project if the need arises, for example, if the economy grows at a lower than the projected rate. This issue is discussed further in section (4).

\subsection{Increasing productivity and incomes in the rural economy while maintaining its labor absorptive capacity}

With almost half of the labor force engaged in the agriculture sector and with around 70 per cent of the labor force working in rural areas the strong emphasis on the development of the rural economy in both the PRSP and the MTDF is more than justified. In relation to agriculture the importance of needed water resources and how best to deliver them is also rightly emphasised in both these documents. The same is the case for the development of the livestock, poultry and dairy industry in the rural areas as well as other initiatives outlined earlier.

One of the proposals outlined in the MTDF is the distribution of state owned lands to landless labor which has proved very successful, as in the Punjab, in reducing poverty levels of this vulnerable group. It would be helpful if the MTDF was to provide some estimates of the expected land acreage to be so distributed and the number of landless labor that this scheme would target. 
What is not so clear in the MTDF is whether the giving out of nonirrigated state land for corporate farming would reduce the land available for distribution to landless labor and whether it may still be better to develop these lands with public investment and then distribute them amongst the landless.

Indeed the whole issue of introducing corporate farming even on unirrigated state land needs more careful examination. If the idea is then to extend this scheme to even irrigated state land or allowing foreign investors to undertake corporate farming by buying out small landholdings, it could seriously undermine the labor absorptive capacity of the rural economy. At this stage it seems pre-mature to encourage corporate farming even if one wishes to use this mechanism to stop the fragmentation of land into very small land holdings.

To be pragmatic the agriculture sector must provide a breathing space for the economy to absorb the high rate of growth of the labor force. The need is to increase productivity of those employed in the sector through making available the relevant technologies many of which already exist for local use. ${ }^{13}$

Also pricing policies for the outputs of the agriculture sector need to take into account the economic conditions of small marginal farmers without or limited marketable surplus and landless non-farm households in the village communities whose number is close to one-half of the entire households in many villages in Pakistan.

A serious effort should also be undertaken to study the behavior of the land market and to explore the possibility of owning land by those who do not have the initial capital to do so, keeping in mind that the extreme disparities in land ownership and incomes of those who own land as compared to those who do not. The schemes outlined earlier for the distribution of state owned land to the landless must be viewed in this context.

\subsection{Promoting local development, empowering local communities and upscaling successes}

Poverty levels could be substantially reduced and job opportunities created through greater autonomy and use of resources at the local level based on a local development strategic framework. There is need to assist decentralized authorities to identify local employment opportunities and to

13 See S, Hirashima, Comments on Decent Work: An Employment and Poverty Reduction Strategy for Pakistan, JICA, Islamabad (Note). 
incorporate elements of basic social protection. Public-private partnerships and participatory process should be encouraged.

Pakistan has a number of success stories in promoting local development through a participatory process of which the Aga Khan Rural Support Program (AKRSP) is a prime example. ${ }^{14}$ The Pakistan Rural Support Program has built on this experience and its development activities in the rural areas now covers 27 districts of all the four provinces and Azad Jammu and Kashmir. As of February 2002 the National Rural Support Program had formed around 15,500 community organizations with a membership of around 326,00 of which 30 per cent were females.

An example of community based initiative to impart short-term training at the local level is the ILO's TREE (Training for Rural Economic Empowerment) project implemented with national partners including the National Rural Support Program and Directorates of Technical Education which has been very successful in training people mostly for self employment in three districts in the NWFP and Punjab Province. It has targeted persons belonging to low income families, rural women, unemployed young males and people with disabilities with a very high success rate. Pilot programs such as the TREE project and other successful initiatives need to be up-scaled and expanded to different parts of the country.

Over the past many years a number of NGO's (eg. Sungi) have done very impressive work on a smaller scale in encouraging community based development. Yet there is still not sufficient recognition or support at the national or provincial level of the important role they could play in generating local employment opportunities. The changes brought in through the devolution process to empower local level government in 2001 provides an opportunity to encourage, enlarge and expand upon such local level initiatives by providing support to community based development initiatives, especially through the provision of micro credit and community based skill development programs. The existing community based organization could also assist in the training and strengthening of the new District governments and local bodies being set up.

\footnotetext{
${ }^{14}$ For a summary review of the underlying strategy and philosophy of participatory development see Fayyaz Baqir, A Module on Participatory Development based on the lessons by Dr. Akhter Hameed Khan (late). Institute of Rural Management, National Rural Support Program, Islamabad.
} 


\subsection{Creating a favorable environment for entrepreneurship development and enterprise development especially for small and medium enterprises}

It is entrepreneurs, in small and big enterprises, in the formal and informal economy, who play a major role in bringing in new investment thus raising production and job creation.

Business initiatives should not be taken for granted. A favorable policy environment needs to be created by simplifying and reducing regulatory procedures for setting up new businesses, encouraging competition in product markets and by having greater transparency in awarding contracts and regulating businesses.

Women entrepreneurship needs to be promoted through training in basic business skills and improved access to credit and market opportunities.

Pakistan's PRSP but more especially the MTDF spells out a detailed strategy and concrete policy measures for the development of SMEs. It also suggests a uniform definition for SMEs which would make it easier to track growth of this sector.

Measures outlined in the MTDF include: (i) technology up-gradation and enhancement of business skills; (ii) increase in competitiveness of SMEs including through provision of subsidized focused short duration training module to workers and their shop floor managers; (iii) incentives for investment in the form of reduced taxes for enterprises which sign up for up-gradation of business products; (iv) improve quality standards to compete in the global economy; ( $v$ ) improve market access and product information; (vi) strengthening of legal, taxation and institutional framework; and (vii) improved access to financial resources and services including a substantial increase in share of total bank financing for SMEs and credit as venture capital for new start-ups especially those engaged in export-oriented contract manufacturing.

The MTDF reiterates the demand of the sector for the redrafting and implementation of less intrusive labor laws and involvement of trade bodies in the inspection process. The MTDF, however, takes the view that since important elements of social equity are involved, incentives would be offered in the form of reduced costs of credit, inputs and tariffs if owners voluntarily comply with Employees Old Age Benefit Insurance and Employees Social Security Institution. 
The role of the Small and Medium Enterprise Development Authority (SMEDA) in actively promoting the growth of this sector and the SME Bank to provide financial support to SMEs including financing schemes for women entrepreneurs are highlighted in both the PRSP and the MTDF. The latter also lists a number of high priority activities in manufacturing, design and services including call centers for investment by SMEs. Assistance from the Asian Development Bank has also been sought by the Government to encourage reforms and growth of this sector.

Given the dominant role of SMEs amongst private sector enterprises (90 per cent employ less than 99 workers in manufacturing) and the fact that the vast majority of new jobs will be created by them, the high priority being given to encourage growth of this sector is well placed and many new initiatives are planned.

Yet it needs to be realized that it is impossible to micro manage the growth of this sector given its size despite some well intentioned assistance to a small number of enterprises. What needs more careful analysis is the overall incentive structure especially the regulatory framework for setting up new businesses and encouraging competition in product markets and the impact of such measures on the growth of SMEs. What would be very helpful is an analysis based on for example the Census of Small Scale Manufacturing Enterprises to track the growth of this sector as was done for the period of the 1970s and 1980s.

This is all the more important as growth in manufacturing in recent years is attributed mainly to a few large scale enterprises from established large industrial houses in textiles and other key sectors. Also it is not quite clear whether any significant investment has taken place in SMEs in the past few years especially in manufacturing.

There is therefore an urgent need to conduct an analysis of the growth of the SME sector in the recent past which should include the impact of trade liberalization on SMEs' capacity to compete in the global economy. The issue of the labor regulatory framework on inhibiting growth and new investment needs to be judged looking at relative performance of enterprises in this sector. While opinion based surveys may be helpful in this regard they are no substitute for an analysis based on actual performance and identification of factors which help explain varying performance of SME enterprises. 


\subsection{Increasing the employment intensity of the Public Sector Development Program.}

Experience in the infrastructure and construction sectors has shown that investment programs using employment-intensive construction techniques when compared to conventional equipment-intensive techniques are: (i) at least 30 per cent cheaper; (ii) able to reduce foreign exchange requirements by 30 to 40 per cent; and (iii) create 3 to 5 times more employment per unit of investment without compromising the quality of the end product.

With the same level of public sector investment the Government can strongly influence the rate of job creation by: (i) diverting resources to more employment-intensive programs; and (ii) using more employment-intensive techniques for approved projects.

The Public Sector Development Program (PSDP) is envisaged to increase from 3.3 per cent of GDP in 2004-05 to 7 per cent in 2009-10. The annual PSDP is to triple from around Rs. 202 billion in 2004-05 to Rs. 605 billion in 2009-10 with a total of Rs. 2094 billion over the Five Year period.

Table-3: Sectoral Breakdown

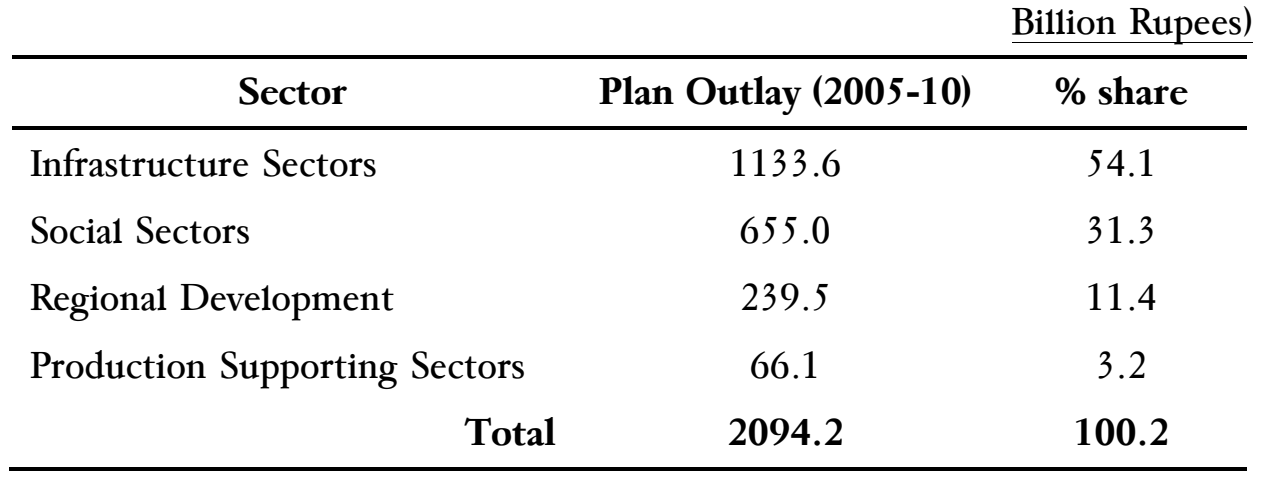

Source: MTDF (2005)

Under infrastructure 15.1 per cent of the total outlay is for the development of water resources, 23.2 per cent for power and 15.6 for transport and communication. Under the social sectors education and training are 5.5 per cent of the total outlay, higher education a significant 4.7 per cent, science and technology 2.9 and IT 1.2 per cent. Local/District Governments are only allocated 2.8 per cent of the total outlay under Regional Development. 
While a more detailed analysis would be required, the MTDF outlay suggests that taking into account the on-going mega infrastructure projects that would be completed during 2005-10 the direct employment generating impact of the PSDP may not be as high as expected and the allocation of expenditures and choice of projects may need to be reviewed.

The employment intensity of the PSDP as outlined in the MTDF may for example be increased by shifting some resources towards projects for local level development such as public works programs and by increasing resources allocated for Local/District level implementation while ensuring that sufficient capacity is built up at this level to be able to execute such projects in a timely, efficient and cost-effective manner.

The employment impact of already selected public sector infrastructure projects could be increased by selecting more labor-based technology and implementing them through small contractors using locally produced raw materials. The MTDF outlines a number of measures and training programs for officials in charge of monitoring and implementation of the PSDP to ensure its timely and cost effective implementation. Such training could include examining ways and means of increasing the labor intensity of selected projects including the mega infrastructure projects.

\subsection{Developing a globally competitive workforce}

The increasing pressures of competitiveness in the global economy has made Pakistan very conscious of the low level of education and skills of its work force. This is not only reflected in the PRSP and MTDF but also in the Prime Ministers 5-Point program which targets an output of 300,000 skilled workers every year - an almost doubling from the 160,000 being produced annually through the existing formal training system.

Efforts to develop a "knowledge economy" which would provide Pakistan the cutting edge at the global level include significantly increased resource allocations for: (i) higher education, with enrolment at tertiary level education increasing from around 4 per cent at present to 8 per cent by 2010, (ii) science and technology and research and development; and (iii) improvements in ICT infrastructure.

The MTDF envisages a very ambitious increase in the number of institutions (2649) to be set up under the new proposed Technical and Vocational Authority (TEVTA) with an annual intake of 838,000 at a capital cost of Rs. 70 billion and recurring cost of Rs.17.5 billion. The target is to increase TEV'T capacity from 0.86 of total enrolment up to higher secondary 
leve1, age groups 10-16 to 2.75 of enrolment in this age group. The number of apprentices is to be more than doubled from around 40,000 to around 100,000 as well as steps taken to formalize the existing informal ustaadshagird (student-teacher)system.

While there is considerable merit in focussing attention on improving skill levels of the work force, the proposed strategy appears to be principally supply driven. It is not clear how the targets have been arrived at and how they relate to the expected increase in demand for skills. While mechanistic projections of demand for skills is rarely warranted, a careful analysis of the expected fast growing sectors and more importantly placement of existing graduates from these institutions and wages for skilled workers should provide a good idea of whether this large increase is justified given the high cost of technical education as compared to more general education. It may also be important to relate the expected increase in demand for skills with skills demanded overseas for which Pakistan could effectively compete.

The planned increase in the capacity of the TEVTA system also needs to pay attention to the quality of the graduates, their acceptance by the private sector and how the increased demand for good quality trainers would be met. Successful training efforts based on public-private partnership and tripartite Skills Development Councils need to be replicated and up-scaled.

\subsection{Striking the best possible balance between flexibility in the labor market for enabling enterprises to adjust while providing security for workers}

With respect to the functioning of the labor market and its impact on employment and poverty alleviation there is a distinct difference in approach between the PRSP and the MTDF. While the former views the labor market and the regulatory framework that governs it primarily from its impact on efficiency and competitiveness of enterprises, the latter also views it in relation to its impact on equity and its role in alleviating poverty.

The essential argument in the PRSP is the importance of lowering the cost of doing business as this would encourage job creation and therefore the need for the consolidation of around 101 labor laws into laws and enforcement so that they may have a positive impact on employment and economic growth. A proposed labor market study ${ }^{15}$ also argues that labor market regulations and practices in Pakistan appear to be stringent, contributing to undesirable labor market outcomes and poverty, and

\footnotetext{
${ }^{15}$ Asya Akhlaque and Milan Vodopivec (2005)
} 
hindering overall growth. It argues that to circumvent the rigidities of labor laws that apply to units with 10 or more workers, employers have resorted to a combination of sub-contracting of production, harnessing of capital intensive production processes, hiring of contract labor, and fragmentation and legal subdivision of production facilities into smaller enterprises. The study claims that as a consequence Pakistan has at 36 per cent the highest share of temporary or contract employees as a percentage of total employees in the formal manufacturing sector as compared to its two South Asian neighbours India at 15 per cent and Bangladesh at 3 per cent.

Without pre-empting the results of the cited study it could be said that the deteriorating labor market situation reflected in rising unemployment, stagnant and declining wages in the 1990s till recently and resulting weakening position of trade unions have all led to a very flexible labor market and flexible labor market arrangements and that the labor regulatory framework in such a situation is easily ignored and difficult to implement. The increase in contract labor arrangements and other measures may well be a reflection of these developments.

This is an opportune time to discuss the existing labor regulatory framework as the labor legislation promulgated in October 2002, the IRQ 2002, has curtailed workers' rights and the Committee of Experts that reviews the implementation of International Labor Standards has made it clear that various provisions of the Ordinance are not in conformity with Convention 87 (Freedom of Association and Protection of the Rights to Organise) and Convention 97 (Right to Organise and Collective Bargaining) to which Pakistan is a signatory. ${ }^{16}$ It was also unfortunate that the promulgated IRO 2002 completely disregarded the agreement reached between the employers, workers and the government in the National Tripartite Labor Conference held in August 2001.

The PRSP makes it quite clear that the Government aims to formulate a labor policy that would ensure protection to workers' rights in all sectors and fair working conditions while enhancing labor productivity and encouraging enterprise efficiency and competitiveness. ${ }^{17}$ Also a Labor

\footnotetext{
${ }^{16}$ See ILO, Report of the Committee of Experts on the Application of Conventions and Recommendations, Application of International Labor Standards 2005, Geneva, 2005.

${ }^{17}$ The First Draft of the Labor Protection Policy 2005 was circulated in February 2005 for discussion. The Draft Policy expands the scope of its application by including 'all categories of workers engaged under informal arrangements....' And it covers five main areas including: basic rights; working conditions; working environment; social security and living environment. The Draft Policy clearly recognizes the linkage between development and labor protection. And seeks to commit to a new Labor Inspection Policy.
} 
Inspection Policy will be formulated which will adopt an innovative approach to labor inspection that is flexible, transparent and fair and encourage enterprise compliance with labor policies and laws. The Government is also in the process of consolidating and rationalizing various labor laws into six broad categories in line with ILO conventions ratified by Pakistan to reduce the cost of doing business.

This new labor legislation needs to be developed through tripartite social dialogue and consensus between employers, workers and the Government and the need for such consultations and dialogue between stakeholders is emphasised in the PRSP.

\section{Minimum Wage}

The MTDF proposes the establishment of a minimum wage to be set by the Government in such a way so as to ensure elimination of the working poor to a very large extent. This is seen as an essential part of the measures for providing a safety net and security to workers.

The minimum wage law of 2001 which replaced an earlier law dating back to 1969 has not only revised the minimum wage, but has also extended its application to employees of all industrial and commercial establishments as the earlier law was restricted to those establishments that employed at least fifty workers. The minimum was set at Rs. 2500 per month which is currently being renegotiated. According to the Labor Force Survey over half the employees have salaries below the minimum wage. ${ }^{18}$

There are arguments for and against a minimum wage law as an effective policy for poverty reduction. An argument against is that it distorts the labor market and might drive up wages but may drive down employment. Arguments for minimum wages point to the possibility that labor markets, especially those where the poor are to be found, are already distorted, and a minimum wage might serve to correct the distortion. It could also have a favorable impact on productivity.

The fact that in Pakistan labor markets are segmented, along lines of gender or social grouping suggests that labor markets are not competitive in the first instance. ${ }^{19}$ Many such sections of the population are especially disadvantaged and this is then reflected in their wages. Real wages of rural

\footnotetext{
${ }^{18}$ The discussion on the minimum wage is based on Harris Gazdar, An Employment Based Poverty Reduction Strategy for Pakistan, in PIDE (2004).

${ }^{19}$ See Gazdar (2004)
} 
labor for example has not gone up in recent years while wages of workers in other sectors have increased.

The issue of a national minimum wage policy as proposed in the MTDF therefore needs to be seriously pursued as an effective measure for poverty alleviation by expanding its scope to all workers regardless of sector, industry or type of establishment and not only to workers of commercial and industrial establishments. Such a minimum wage should also take into account variations in labor market conditions across regions. Clearly there are serious hurdles in the way of the implementation of a national minimum wage especially in the informal and rural economy. Initially it may more serve as a guideline in fixing wages in such sectors and indirectly serve to improve the bargaining position of disadvantaged groups in the labor market.

Debate and discussion of the issue of a national minimum wage may therefore be initiated as part of the discussion on the MTDF.

\subsection{Improving productivity, conditions of work and incomes in the informal economy}

It is somewhat surprising that given the fact that almost 70 per cent of the non-agricultural labor force is employed in the informal economy and that most new jobs have over the recent years been created in this sector, both the PRSP and the MTDF do not explicitly target this sector. However, a number of measures outlined in both these documents especially the provision of micro credit and other direct support measures to assist the working poor would be targeted at this sector.

Yet there is perhaps a real need to explicitly recognize this sector in the Government's strategy for enhancing employment and incomes and alleviating poverty. Most micro enterprises and especially self-employed women are found in this sector and many of the measures outlined for the support of the SME sector are not really applicable to this sector.

For the Government to recognize the existence of the informal economy would in itself be an important step as it could lead to measures to recognize the assets of those working in this sector and to be able to use it as collateral for gaining access to credit and other services.

Policies must aim to stimulate the economic environment under which the informal economy operates, especially linkages with the more dynamic sectors of the economy together with innovative approaches for 
initiating a growth process and institutional reforms to integrate the informal economy into the economic mainstream.

To improve working conditions in the informal economy integrated policies are needed to raise productivity, improve working conditions, develop affordable social protection, set up skills upgrading programs, ensure a legal and institutional framework for property and labor rights and giving a voice to those who work in this sector by encouraging workers to organize themselves.

The 'product market' divide between the formal and informal economy needs to be overcome through the use of value chain analysis and marketing approaches and tools to identify links in the production chain which can be favorably opened up for producers in the informal economy.

There is a need to strengthen the capacity of policy makers at the local level to provide a conducive policy framework and support structures for market access for informal sector operators.

Developing and empowering women entrepreneurs should be a major target of public agencies as well as NGOs working in the informal economy. The SME Bank and its women entrepreneurship development program may be well beyond the reach of women working in this sector. A survey carried out by the ILO of women borrowers in Punjab, Balochistan and NWFP who obtained micro-finance services from three NGOs namely National Rural Support Program (NRSP), Sungi Foundation (SF) and Traqi Trust (TT) between 1996 and 2001 found that the majority (71 per cent) of women entrepreneurs reported a positive change in their status in the family and community after their enterprises had improved through the use of credit. While the survey revealed that the repayment rate among women borrowers is fairly satisfactory, the interest rate charged on loans varied between 10-20 per cent but reached the level of 34 per cent when calculated on the basis of the outstanding balance. ${ }^{20}$

The setting up of a Micro Bank is a good start in meeting the financial needs of the informal economy but if it is to have any real impact its operations would need to be drastically increased building upon its experience.

\footnotetext{
${ }^{20}$ M. Sabrina de Gobi et.al., Nepal and Pakistan: Micro-Finance and Micro-Enterprise Development-Their Contribution to the Economic Empowerment of Women, SEED Working Paper No. 69, Joint SEED/SFP Publication, ILO, Geneva, 2004.
} 
The other area which needs urgent attention is improving conditions of work in the informal economy. As the Labor Force Survey 2003-04 has shown the highest incidence of occupational injury and disease are the selfemployed. The returns to investment and campaigns to increase awareness on occupational, safety and health in the informal economy can be very high with a favorable impact on productivity and incomes of those employed.

\subsection{Maximizing development benefits from overseas migration and Remittances}

Overseas migration and resulting remittances has played an extremely important role in reducing pressures on the domestic labor market and in reducing poverty especially from the mid-1970s to the mid1980s. The MTDF clearly identifies overseas migration as one of the major areas of demand for Pakistani workers during 2005-10.

The post 9/11 increases in remittances clearly contributed to improving the macro fundamentals and the turnaround in the economy that followed. Since these increases have not been the result of any significant out migration flow its impact on this account has been minimal. Also it would appear that this increase is coming from mainly more well to do overseas Pakistanis and its impact has been much more on the real estate market and housing construction rather than on stimulating demand for consumer goods as had happened in the 1980 s. $^{21}$ To that extent its impact on stimulating demand and employment has been much less as compared to the 1980s.

The MDTF does identify skills in demand overseas as well as countries especially in South-East Asia and the Middle-East where Pakistan migrant workers could find gainful employment.

What may be very useful at this stage is to conduct a sample survey on the use of remittances sent by overseas Pakistanis to their families in Pakistan and, if possible, on the reasons for their increase by interviewing overseas Pakistanis in their host countries.

The results of such a survey could assist in formulating policies for the more productive use of these remittances and thereby help in stimulating growth and employment. These could relate to facilitating

21 See Rashid Amjad, Remittances and Development in South Asia: Post 9/11 Developments, South Asian Journal, No. 6 October -December 2004. 
investments by overseas Pakistanis in real estate, housing, stock market and investments in the ICT sector. ${ }^{22}$

In recent years donations by overseas Pakistanis have been used through the setting up of a National Commission for Human Development supplemented by government funds to launch programs for elementary education and improved health facilities at the local level.

Overseas Pakistanis may also be attracted to contribute to local economic development projects in areas from where they migrated. Such a project proposal has been supported by the UK Resident Kashmiri Community which numbers around 500,000 for the creation of sustainable job creation and livelihood opportunities in certain districts in Azad Kashmir. The project is being developed by the ILO in partnership with DFID and the Government of Azad Kashmir. Similar proposals could be developed with other Pakistani communities living abroad.

\subsection{Mainstreaming Gender Equality}

Women in Pakistan still remain an overworked, neglected and underpaid human resource who if educated, empowered and integrated into productive and remunerative economic activities could make a major contribution to increasing productivity, stimulating economic growth and reducing poverty in Pakistan.

A holistic approach towards the economic empowerment of women is to ensure their workers rights by ensuring non-discrimination and equality at the workplace; by developing their skills levels for effective participation in the labor market, especially by developing their entrepreneurial capabilities; by strengthening their participation in trade unions for effective bargaining and voice representation particularly for securing adequate social protection and by encouraging the private sector to develop affirmative action strategies. The ILO Women's Economic Concerns and Working Conditions project is a step towards demonstrating this approach.

There have been some impressive developments in empowering women in the last few years especially in increasing significantly their representation in the national and provincial legislature and in local bodies. Both the PRSP and the MTDF outline in great detail these achievements and both the documents have separate chapters outlining

${ }^{22}$ See Shahid Javed Burki, Utilizing Expatriate Money, Dawn, 19 April 2005. 
strategies for bringing about significant improvements in the status and active participation of women in economic activities.

The employment chapters in these documents, however, do not focus sufficiently on the gender disparities in the labor market reflected in the very low participation rates of females and very high levels of unemployment.

Of the few women who do participate in the labor market and are part of the labor force in that they are willing and actively seeking work, the unemployment levels are extremely high. Overall the unemployment rate of females in 2003-04 was 12.8 per cent almost double that of the overall rate. Unemployment of females is especially high in urban areas, almost 20 per cent overall. In Balochistan and NWFP Provinces unemployment rates for females is around 30 per cent. Female unemployment in the age group 15-24 years is also 30 per cent.

These very low participation rates and high unemployment rates amongst females need urgent action as it could act as a strong disincentive to invest in female education which is the most important means of empowering women in Pakistan. Attention must be paid to improving the environment and conditions in which women work as this may be a discouraging factor in women wishing to work outside their households. Also the question of improving facilities to encourage mobility of women, including the educated, from their households to their possible places of work needs to be acted upon as this could also discourage women to go to relatively far away places for work even if employment exists in those areas.

Some measures have already been initiated to encourage selfemployment and women entrepreneurship through the setting up of the First Women Bank and actions by the Pakistan Rural Support Program and other NGOs mentioned earlier with a measure of success but these still remain marginal in terms of their overall coverage and impact.

Poor women feature prominently among the chronic poor in Pakistan as in the rest of South Asia. Labor market segregation along gender lines restricts the employment opportunities for women. Despite legal provisions to protect women's ownership rights - which might prevent women from slipping further into poverty - discriminatory and patriarchal property and inheritance customs continue to prevail. Chronic poverty is also positively correlated in Pakistan with areas in which tribal and or feudal agrarian relations prevail - including the Federally Administered Tribal Areas and large areas of Balochistan. The causes of the relative higher poverty of 
these areas are related to their physical remoteness, lack of infrastructure, high population growth and scarcity of farmland and not to the status of the tribal people as such.

It would be important to build into the employment strategy in the MTDF concrete ways and means of addressing the gender discrimination in the labor market as well as the high rates of unemployment especially among the young and educated women. A more targeted approach for the educated unemployed and chronically poor women may be warranted. As regards the former, matching education and skills more closely to market demand especially in new emerging sectors such as IT and media and in the case of the latter more targeted programs for chronically poor women could be spelt out.

Finally, while it is true that the present Government has taken many bold steps to empower women over the past few years, what is perhaps missing is a clear and strong signal to all those engaged in policy making and in the administrative and policy structure of the strong commitment and resolve of the Government to ensure that its policies on empowering women and improving their status are carried out.

\section{Conclusions}

A review of the Government's policies as is reflected in its Poverty Reduction Strategy and the MTDF 2005-10 shows that the Government is giving high priority to the creation of productive and remunerative employment and embedding this goal in its poverty reduction programs. This is a sharp break from earlier Plans and programs.

The paper has reviewed the overall policy environment and incentive structure for the expansion of employment in the economy including in key sectors and the importance and urgency of improving the education and skill levels of the country's work force to compete in the global economy.

In so doing the paper has identified some critical gaps and come up with suggestions on how to ensure that the goals that have been set in the PRSP and MTDF can be effectively achieved. Some of the suggestions relate to:-

- Trying to build in more flexibility in the Public Sector Development Plan to switch to more employment generating projects as the need so arises and examining ways of increasing the employment impact of the existing and planned projects. 
- The importance of maintaining the existing labor absorptive capacity of the agricultural sector while increasing productivity and incomes of those employed in the sector. In this context the proposals for introducing corporate farming need to be critically examined.

- While targeted measures for encouraging the growth of SMEs especially through SMEDA and other agencies are welcome, given the vast size of this sector, the real need is to ensure an overall favorable environment to encourage its growth. This includes reviewing the existing incentive structure and the possible impact of the new WTO regime on its growth prospects.

- In developing its ambitious skill training program there is need a to move from a supply driven approach to one more closely responding to market demand and ensuring cost effectiveness and reasonable rates of return on investments in skills training.

- Recognition of skills including those acquired on the job and outside the training system as part of a national qualifications framework would make the existing system more flexible to rapidly changing skill requirements.

- Other active labor market policies (ALMPs) in addition to training such as provision of employment services closely linked to skill centers at the district or tehsil level should be considered to better match supply and demand in the labor market.

- In carrying out the planned reforms in the labor regulatory framework there is need to ensure the best possible balance between flexibility for enterprises to adjust to changing market demand and security for workers while fully respecting international labor standards. It is equally important that the changes introduced should be developed through social dialogue and tripartite agreement.

- There is merit in considering the setting up of a national minimum wage for lifting the working poor out of poverty and this measure outlined in the MTDF needs serious discussion and consideration.

- Strengthening the institutional capacity of the labor administration system is required. 
- An affordable social protection system and social safety nets should be put in place through innovative programs and micro-finance initiatives.

- The need for the Government to recognize the existence of the informal economy which is not explicitly done in the PRSP and the MTDF as this in itself could play an important part in putting in place measures that lead to recognition of rights and assets owned by those working in the sector.

- Maximizing the development benefits from overseas migration and remittances and to tap resources from overseas Pakistanis for local economic development projects in the areas from where they migrated and where many members of their families still reside.

- The employment chapters in both the PRSP and the MTDF need to address the wide gender disparity and to focus on targeted measures for reducing high levels of unemployment amongst young women.

- The importance of developing a rights based labor market in Pakistan to ensure that the poorest groups participate and gain in the development process and its importance for ensuring access for its products in export markets in the new WTO regime. 


\section{References}

A.R. Kemal, Employment-Poverty Linkages and Policy in Pakistan, ILO Working Paper, Geneva, 2005.

Asad Sayeed. Social Protection in Pakistan: The Concept, Situation Analysis, and the Way Forward in proceedings of a joint seminar organised by the Planning Commission. ILO and UNDP on Employment-based Poverty Reduction Strategy for Decent Work in Pakistan. Pakistan Institute of Development Economics, Islamabad, December 2004.

Asya Akhlaque and Milan Vodopivec, Generating Investment and Employment opportunities in Pakistan through Labor Market Reforms: Concept Note for the Proposed Labor Market Study. Islamabad, 2005

Fayyaz Baqir, A module on Participatory Development based on the lessons by Dr. Akhter Hameed Khan (late), Institute of Rural Management, National Rural Support Program, Islamabad.

Government of Pakistan, Labor Force Survey 2003-04, Federal Bureau of Statistics, Islamabad.

Government of Pakistan, Poverty Reduction Strategy Paper. Accelerating Economic Growth and Reducing Poverty: The Road Ahead, Poverty Reduction Strategy Secretariat, Ministry of Finance. Islamabad. December 2003.

Government of Pakistan, Working Draft, Medium Term Development Framework 2005-10, Planning Commission, Islamabad, March 2005.

Harris Gazdar, An Employment Based Poverty Reduction Strategy for Pakistan, in PIDE (2004).

International Labor Organization, Report of the Committee of Experts on the Application of Conventions and Recommendations, Application of International Labor Standards 2005, Geneva, 2005.

M. Sabrina de Gobi et.al., Nepal and Pakistan: Micro-Finance and MicroEnterprise Development - Their Contribution to the Economic Empowerment of Women, SEED Working Paper No. 69. Joint SEED/SFP Publication, ILO, Geneva, 2004. 
Rashid Amjad, Remittances and Development in South Asia: Post 9/11 Developments, South Asian Journal, No.6 October -December 2004.

Rashid Amjad, Solving Pakistan's Poverty Puzzle: Whom Should We Believe? What should We Do?, Pakistan Development Review, Volume 42, Number 4, Winter 2003, Islamabad.

S. Hirashima, Comments on Decent Work: An Employment and PovertyReduction Strategy for Pakistan, JICA, Islamabad (Note).

Shahid Javed Burki, Utilizing Expatriate Money, Dawn, 19 April 2005.

Sohail J. Malik, Agriculture Growth and Rural Poverty, Working Paper No. 2, Pakistan Resident Mission Working Paper Series, Asian Development Bank, Islamabad, 2005. 